\title{
Penerapan Metode Double Exponential Smoothing dan Moving Average pada Peramalan Permintaan Produk Gasket Cap di PT. Nesinak Industries
}

\author{
Muhammad Hafidh Kurniawan $^{1 *}$, Dene Herwanto ${ }^{2}$ \\ ${ }^{1,2}$ Teknik Industri, Fakultas Teknik, Universitas Singaperbangsa Karawang, Karawang \\ *Koresponden email: hafic12@gmail.com
}

Diterima: 6 November 2021

Disetujui: 13 Desember 2021

\begin{abstract}
PT. Nesinak Industries is a company which focuses on the manufacturing process of an electronic component as well as automotive components (vehicle). In business activities, such as production, a strategy is required to survive in competition. Planning and forecasting are a strategy that can be implemented to accomplish these goals. In this study, the data used are previous sealing application data from January 2019 to March 2021. The objective of this study is to forecast product demand over the next period in order to be able to respond to customer demand. Data processing in this study utilize the Brown exponential double smoothing method and the moving average is then determined with the lowest MAPE (Mean Absolute Percentage Error) value to be used for the company's product demand prediction calculations. The value of taken from Brown's exponential dual smoothing method is the value of with the two lowest error values from 0.1 to 0.9 , whose value with the least error value is $=0.8$ and $=0.9$. In terms of the moving average method, the researchers tested a period of three months and a period of four months. In the MAPE calculation, the results of exponential double smoothing $=0.8$ of $26.92 \%$, exponential double smoothing $=0.9$ of $26.22 \%$, moving average $n=3$ of $32.46 \%$, and moving average $n=4$ of $34.77 \%$.
\end{abstract}

Keywords: forecasting, moving average, double exponential smoothing, mean absolute percentage error, Brown

\begin{abstract}
Abstrak
PT. Nesinak Industries adalah perusahaan yang berfokus pada proses pembuatan suatu komponen elektronik dan juga komponen otomotif. Pada kegiatan produksi, sebuah strategi diperlukan agar dapat bertahan pada persaingan. Peramalan merupakan suatu strategi yang dilakukan dalam mencapai hal tersebut. Pada penelitian ini, data yang digunakan merupakan data masa lalu permintaan produk gasket cap dari Januari 2019 sampai dengan Maret 2021. Penelitian ini ditujukan untuk meramalkan permintaan produk pada periode selanjutnya untuk dapat memenuhi permintaan pelanggan. Pengolahan data pada penelitian ini menggunakan metode double exponential smoothing dari Brown dan moving average kemudian ditentukan dengan nilai Mean Absolute Percentage Error terendah yang digunakan pada peramalan permintaan produk di perusahaan tersebut. Nilai $\alpha$ yang diambil dari metode double exponential smoothing dari Brown merupakan nilai $\alpha$ dengan nilai error dua terendah dari 0,1 sampai dengan 0,9 didapatkan nilai $\alpha$ yang memiliki nilai error terendahnya yakni $\alpha=0,8$ dan $\alpha=0$,9. Sedangkan untuk metode moving average peneliti menguji dengan periode 3 bulanan dan periode 4 bulanan. Pada perhitungan MAPE didapatkan hasil untuk double exponential smoothing $\alpha=0,8$ sebesar $26,92 \%$, dan $\alpha$ $=0,9$ sebesar 26,22 \% sedangkan moving average $\mathrm{n}=3$ sebesar 32,46\%, dan $\mathrm{n}=4$ sebesar $34,77 \%$.

Kata Kunci: peramalan, pergerakan rata-rata, pemulusan eksponensial ganda, rata-rata kesalahan persentase absolut, Brown
\end{abstract}

\section{Pendahuluan}

Pada masa persaingan bisnis yang semakin ketat, perusahaan perlu melakukan perencanaan dengan baik, salah satunya melalui peramalan. Hal ini dilakukan sebagai upaya memberikan kepuasan pada pelanggan dengan cara memenuhi permintaannya. Peramalan juga merupakan alat bantu dalam sebuah perencanaan. Dalam perusahaan peramalan digunakan sebagai mengestimasi atau memprediksi permintaan yang akan datang sehingga mengetahui estimasi jumlah dari suatu produk yang akan diproduksi. Pada konsep peramalan, hasil yang didapatkan bukan merupakan hasil mutlak yang sudah pasti, melainkan berupa kemungkinan yang dapat terjadi sehingga pihak manajemen dapat menentukan strategi terbaik berdasarkan hasil peramalan tersebut. Peramalan merupakan sebuah seni dari paham yang fokus pada 
prediksi sesuatu yang belum pasti terjadi. Hal ini bertujuan untuk memperkirakan kemungkinan peristiwa yang dapat terjadi di masa depan dengan menggunakan data masa lalu [1]. Penggunaan peramalan ditujukan khususnya untuk proses analisis kinerja yang dilakukan kemudian memperkirakan kemungkinan yang dapat terjadi dimasa depan untuk mengetahui kondisi sesuai atau tidak dengan yang diharapkan [2]. Peramalan memegang peranan penting diantaranya :

a. Untuk menjadwalkan sumber daya yang dimiliki.

b. Dalam peramalan permintaan pada objek produk, tenaga kerja, material dapat menjadi input untuk melakukan penjadwalan.

c. Proses peramalan sangat diperlukan untuk memperkirakan kebutuhan sumber daya di masa depan.

d. Mengidentifikasi dan memprediksi sumber daya yang diharapkan.

e. Proses peramalan berguna untuk semua organisasi atau perusahaan dalam penentuan sumber daya yang ingin dimiliki di dalam masa jangka panjang.

PT. Nesinak Industries adalah sebuah perusahaan yang berfokus pada proses produksi komponen elektronik dan juga komponen otomotif (kendaraan). Penerapan metode peramalan untuk memberikan perkiraan permintaan produksi dimasa mendatang pada produk gasket cap di PT. Nesinak Industries. Penerapan metode peramalan ini hanya sebagai estimasi atau perkiraan permintaan produksi dimasa mendatang, mengingat permintaan dalam dunia bisnis selalu berubah-ubah (fluktuatif). Peramalan merupakan sebuah proses memprediksi atau memproyeksikan sebuah ketidakpastian dimasa yang akan datang. Aktivitas peramalan secara umum terbagi menjadi tiga, diantaranya [3].

a. Menjadi sebuah alat bantu dalam proses merencanakan yang efektif dan efisien.

b. Digunakan sebagai alat dalam menentukan kebutuhan sumber-sumber perusahaan dimasa depan.

c. Sebagai alat bantu dalam menentukan keputusan yang tepat.

Manfaat yang menjadi hal apa yang akan didapatkan pada penelitian kali ini diantaranya.

a. Dapat mengetahui perkiraan permintaan produk gasket cap dimasa mendatang.

b. Dapat memudahkan perencanaan produksi dari peramalan sebagai perkiraan produksi.

c. Mengetahui perbedaan hasil perhitungan dari metode double exponential smoothing dan moving average.

Berdasarkan uraian di atas, peneliti membuat penelitian tentang peramalan (forecasting) yang akan memprediksikan permintaan dari data historis yang didapatkan pada Januari Tahun 2019 sampai dengan Maret 2021 melalui penerapan metode peramalan diantaranya Moving average dan Double exponential smoothing dari Brown. Data waktu seri atau deret waktu adalah sebuah data yang dikumpulkan kemudian didokumentasikan dalam suatu periode tertentu. Data deret waktu digunakan pada proses peramalan untuk mengetahui pola variansi pada kondisi masa lalu. Moving average adalah sebuah cara dalam aktivitas peramalan yang prosesnya menggunakan sejumlah data nyata permintaan yang baru untuk dapat membangkitkan nilai peramalan permintaan dimasa depan [1]. Kemudian double exponential smoothing (DES) adalah sebuah cara peramalan melalui proses perhitungan yang berulang dan terus-menerus dengan data masa lalu yang paling baru berdasarkan hasil perhitungan rata-rata penghalusan secara eksponensial.

Metode DES digunakan karena melihat dari kondisi trend pada data yang cenderung naik atau turun dalam periode waktu yang lama [4]. Sedangkan metode moving average digunakan karena untuk mengetahui peramalan dalam jangka waktu dekat dari hasil pergerakan rata-rata yang realtif stabil [5]. Ukuran ketetapan dalam hasil peramalan dengan menggunakan mean absolute percentage error (MAPE) karena indikator variabel pada proses peramalan merupakan sebuah faktor yang memiliki pengaruh dalam proses evaluasi akurasi peramalan yang telah dilakukan. Mean absolute percentage error (MAPE) adalah sebuah persentase yang menunjukkan nilai rata-rata kesalahan peramalan [6]. Penelitian ini ditujukan untuk meramalkan permintaan produk pada periode selanjutnya untuk dapat memenuhi permintaan pelanggan menggunakan metode DES dan MA dengan indikator nilai MAPE.

\section{Metode Penelitian}

Pada penelitian ini terdapat metodologi yang dilakukan untuk menggambarkan proses penelitiannya. Metodologi ini merupakan sebuah konsep secara teoritis berbagai metode, kelebihan, ataupun kekurangan [7]. Adapun isi dari metode penelitian yaitu:

\section{a. Objek Penelitian}

Objek penelitian ini adalah sebuah atribut atau nilai dari suatu objek atau kegiatan yang ditetapkan secara khusus oleh peneliti untuk dipelajari [8]. Objek penelitian yang diamati merupakan produk gasket cap dari PT. Nesinak Industries.

b. Teknik Pengumpulan Data

Ada beberapa cara yang dilakukan dalam pengumpulan data, yaitu seperti berikut: 
1) Wawancara

Proses wawancara ini adalah sebuah pertemuan yang melibatkan dua pihak yang saling bertukar informasi dengan cara bertanya dan menjawab untuk mendapatkan informasi tersebut [9]. Peneliti melakukan tanya jawab kepada atasan perusahaan mengenai topik yang ingin diteliti. Melalui Teknik ini diharapkan dapat diketahui informasi mengenai proses kerja yang terjadi di perusahaan.

2) Dokumentasi

Pada penelitian kualitatif, dokumentasi ini adalah sebuah alat pelengkap dari aktivitas observasi dan juga wawancara [9]. Kegiatan Dokumentasi dilakukan cara mendokumentasikan data atau informasi terkait dengan penelitian seperti dokumen data permintaan masa lalu dan sekarang.

3) Observasi

Teknik observasi ini memiliki sebuah ciri khas bila dibandingkan dengan metode yang lain [9]. Observasi ini dilakukan dengan melihat dan memperhatikan kondisi nyata dari perusahaan untuk dikaji dan dipelajari.

4) Studi Literatur

Pada studi literatur ini dilakukan pengumpulan referensi dan mempelajarinya yang berkaitan dengan kajian penelitian [10]. Peneliti menggunakan metode ini untuk menunjang keseluruhan metode penelitian untuk mendapatkan hasil yang sesuai.

Metode double exponential smoothing dari Brown dipopulerkan untuk penerapan dalam proses mengatasi sebuah perbedaan hasil yang muncul di diantara data aktual dan peramalan ketika terjadi kecenderungan naik atau turun dalam jangka panjang [11]. Terdapat beberapa persamaan yang digunakan pada metode DES yaitu seperti di bawah ini [12]:

a. Penentuan nilai Smoothing yang pertama $\left(S^{\prime} t\right)$

$S^{\prime} \mathrm{t}=\mathrm{a} X \mathrm{t}+(1-\mathrm{a}) \mathrm{S}^{\prime} \mathrm{t}-1$

b. Penentuan nilai Smoothing yang kedua $\left(S^{\prime \prime} t\right)$

$\mathrm{S}^{\prime \prime} \mathrm{t}=\mathrm{a} \mathrm{St}+(1-\mathrm{a}) \mathrm{S}^{\prime \prime} \mathrm{t}-1$

c. Penentuan besar konstanta $(\alpha \mathrm{t})$

at $=2 S^{\prime} t-S^{\prime \prime} t$

d. Penentuan besarnya slope (bt)

$\mathrm{bt}=\frac{\alpha}{1-\alpha}\left(\mathrm{S}^{\prime} \mathrm{t}-\mathrm{S}^{\prime \prime} \mathrm{t}\right)$

e. Penentuan nilai besar peramalan $(\mathrm{Ft}+\mathrm{m})$

$\mathrm{Ft}+\mathrm{m}=\mathrm{at}+\mathrm{btm}$

Metode moving average adalah sebuah cara dalam proses meramalkan permintaan yang dilakukan dengan pengambilan nilai pengamatan dan kemudian dicari rata-rata nilainya untuk digunakan sebagai peramalan di periode selanjutnya [13]. Di bawah ini merupakan rumus moving average untuk mendapatkan hasil dari perhitungan moving average [14].

$$
\mathrm{MA}=\frac{A_{t}}{n}
$$

Dimana :

$\mathrm{n} \quad=$ Banyaknya periode waktu yang dipakai sebagai dasar dalam peramalan.

$\mathrm{A}_{\mathrm{t}} \quad=$ Jumlah permintaan aktual pada periode tertentu $(\mathrm{t})$

MAPE (Mean Absolute Percentage Error) adalah sebuah nilai rata-rata absolut kesalahan dalam suatu periode waktu yang kemudian dibentuk dalam nilai persentase [15]. Di bawah ini merupakan rumus MAPE untuk mendapatkan hasil dari perhitungan MAPE.

$\mathrm{MAPE}=\sum_{\mathrm{i}=1}^{\mathrm{n}} \frac{\left|\frac{(\mathrm{At}-\mathrm{Ft})}{A t}\right| \times 100}{\mathrm{n}}$

Dengan keterangan:

At : Banyaknya permintaan aktual pada suatu periode t.

Ft: Banyaknya peramalan permintaan pada periode $t$.

$\mathrm{n}$ : Banyaknya periode waktu. 


\section{Hasil dan Pembahasan}

Data penelitian didapatkan melalui dokumentasi dari PT. Nesinak Industries dan wawancara dengan staf PPIC, di bawah ini merupakan data yang telah dikumpulkan dari hasil dokumentasi yakni data permintaan gasket cap pada Januari tahun 2019 sampai dengan Maret 2021.

Tabel 1. Pengumpulan Data

\begin{tabular}{ccc}
\hline \multicolumn{2}{c}{ Periode } & Demand \\
\hline Jan-19 & 1 & 320.000 \\
Feb-19 & 2 & 364.000 \\
Mar-19 & 3 & 438.000 \\
Apr-19 & 4 & 340.000 \\
May-19 & 5 & 408.000 \\
Jun-19 & 6 & 328.000 \\
Jul-19 & 7 & 324.000 \\
Aug-19 & 8 & 332.000 \\
Sep-19 & 9 & 404.000 \\
Oct-19 & 10 & 462.000 \\
Nov-19 & 11 & 384.000 \\
Dec-19 & 12 & 364.000 \\
Jan-20 & 13 & 384.000 \\
Feb-20 & 14 & 372.000 \\
Mar-20 & 15 & 480.000 \\
Apr-20 & 16 & 384.000 \\
May-20 & 17 & 450.000 \\
Jun-20 & 18 & 564.000 \\
Jul-20 & 19 & 380.000 \\
Aug-20 & 20 & 520.000 \\
Sep-20 & 21 & 532.000 \\
Oct-20 & 22 & 320.000 \\
Nov-20 & 23 & 192.000 \\
Dec-20 & 24 & 96.000 \\
Jan-21 & 25 & 440.000 \\
Feb-21 & 26 & 340.000 \\
Mar-21 & 27 & 380.000 \\
\hline umber: PT. Nesinak Industries $(2020)$ \\
& &
\end{tabular}

Setelah data dikumpulkan, kemudian langkah selanjutnya yaitu pengolahan data menggunakan metode double exponential smoothing dan metode moving average. Nilai a yang diambil dari metode double exponential smoothing dari Brown merupakan nilai $\alpha$ dengan nilai error dua terendah dari 0,1 s.d. 0,9 didapatkan nilai $\alpha$ yang memiliki nilai error terendahnya yakni $\alpha=0,8$ dan $\alpha=0,9$. Sedangkan untuk metode moving average peneliti menguji dengan periode 3 bulanan dan periode 4 bulanan.

a. Menghitung double exponential smoothing $\alpha=0,8$

1) Penentuan nilai Smoothing yang pertama $\left(\mathrm{S}^{\prime} \mathrm{t}\right)$

$\mathrm{S}^{\prime}=320.000$

$\mathrm{S}_{2}^{\prime}=(364.000 \times 0,8)+(1-0,8)-0,8 \mathrm{~g} \mathrm{n}=355.200$

$\mathrm{S}_{27}^{\prime}=(340.000 \times 0,8)+(1-0,8)-0,8 \times 0,8355.200$

2) Penentuan nilai Smoothing yang kedua $\left(\mathrm{S}^{\prime \prime} \mathrm{t}\right)$

$\mathrm{S}_{1}=320.000$

$\mathrm{S}_{2}=(355.200 \times 0,8)+(1-0,8) \times 320.000=348.160$

$\mathrm{S}_{27}{ }_{27}=(347.278 \times 0,8)+(1-0,8) \times 330.992=344.021$

3) Penentuan besaran konstanta $(\alpha \mathrm{t})$

$\mathrm{a}_{1}=(2 \times 320.000)-320.000=320.000$

$\mathrm{a}_{27}=(2 \times 347.278)-344.021=402.890$

4) Penentuan Besarnya Slope (bt)

$$
\begin{aligned}
& \mathrm{b}_{1}=\frac{0,8}{1-0,8}(320.000-320.000)=0 \\
& \mathrm{~b}_{27}=\frac{0,8}{1-0,8}(347.278-344.021)=13.029
\end{aligned}
$$


5) Penentuan besarnya peramalan $(\mathrm{Ft}+\mathrm{m})$

$$
\begin{aligned}
& \mathrm{F}_{\mathrm{t}+\mathrm{m}}=\mathrm{a}_{\mathrm{t}}+\mathrm{b}_{\mathrm{t}} \mathrm{m} \\
& \text { Untuk } \mathrm{t}=1 \text { dan } \mathrm{m}=1 \\
& \mathrm{~F}_{1+1}=320.000+0(1) \\
& \mathrm{F}_{2}=320.000 \\
& \text { Untuk } \mathrm{t}=2 \text { dan } \mathrm{m}=1 \\
& \mathrm{~F}_{2+1}=362.240+28.160(1) \\
& \mathrm{F}_{3}=390.400 \\
& \text { Untuk } \mathrm{t}=27 \text { dan } \mathrm{m}=1 \\
& \mathrm{~F}_{27+1}=350.535+13.028(1) \\
& \mathrm{F}_{28}=363.564
\end{aligned}
$$

Tabel 2. Hasil perhitungan DES $\boldsymbol{\alpha}=0,8$

\begin{tabular}{cccccc}
\hline $\begin{array}{c}\text { Periode } \\
(\mathrm{t})\end{array}$ & $\begin{array}{c}\text { Demand } \\
(\mathrm{x})\end{array}$ & $\mathrm{S}$ 't & $\mathrm{S}$ "t & $\mathrm{a}$ & $\mathrm{b}$ \\
\hline 1 & 320.000 & 320.000 & 320.000 & 320.000 & 0 \\
2 & 364.000 & 355.200 & 348.160 & 362.240 & 28.160 \\
3 & 438.000 & 421.440 & 406.784 & 436.096 & 58.624 \\
4 & 340.000 & 356.288 & 366.387 & 346.189 & -40.397 \\
5 & 408.000 & 397.658 & 391.404 & 403.912 & 25.016 \\
6 & 328.000 & 341.932 & 351.826 & 332.037 & -39.578 \\
7 & 324.000 & 327.586 & 332.434 & 322.738 & -19.392 \\
8 & 332.000 & $\ldots$ & $\ldots$ & $\ldots$ \\
$\ldots$ & $\ldots$ & 225.811 & 259.109 & 192.513 & -133.191 \\
24 & 96.000 & 121.962 & 149.391 & 94.533 & -109.717 \\
25 & 440.000 & 376.392 & 330.992 & 421.793 & 181.601 \\
26 & 340.000 & 347.278 & 344.021 & 350.536 & 13.029 \\
27 & 380.000 & 3.591 .784 & 3.600 .509 & 3.582 .586 & -35.844 \\
\hline \multicolumn{7}{c}{ Sumber: Hasil pengolahan data $(2021)$} \\
\end{tabular}

Didapatkan hasil rekapulasi dari perhitungan double exponential smoothing $\boldsymbol{\alpha}=0,8$ kemudian hasil ini dilanjutkan untuk menghitung nilai error dari masing-masing periode.

Tabel 3. Nilai Error Perhitungan DES $\boldsymbol{\alpha}=0,8$

\begin{tabular}{cccc}
\hline $\begin{array}{c}\text { Periode } \\
t\end{array}$ & $\begin{array}{c}\text { Error } \\
\text { At-Ft }\end{array}$ & $\begin{array}{c}\text { [Error] } \\
\mid \text { At-Ft }]\end{array}$ & $\begin{array}{c}\text { \%Erorr } \\
(\text { At-Ft)/At*100 }\end{array}$ \\
\hline 1 & & & \\
2 & 44.000 & 44.000 & 12,09 \\
3 & 89.840 & 89.840 & 20,51 \\
4 & -66.784 & 66.784 & 19,64 \\
5 & 41.613 & 41.613 & 10,20 \\
6 & -63.404 & 63.404 & 19,33 \\
7 & -27.826 & 27.826 & 8,59 \\
8 & -434 & 434 & 0,13 \\
$\ldots$ & $\ldots$ & $\ldots$ & $\ldots$ \\
24 & -163.109 & 163.109 & 169,90 \\
25 & 290.609 & 290.609 & 66,05 \\
26 & 9.008 & 9.008 & 2,65 \\
27 & 35.979 & 35.979 & 9,47 \\
\hline \multicolumn{5}{c}{ MAPE } & 26,92 \\
\hline
\end{tabular}

Sumber: Hasil pengolahan data (2021)

Pada Tabel 3 merupakan nilai error yang diperoleh dari hasil perhitungan double exponential smoothing $\boldsymbol{\alpha}=0,8$ pada tiap periodenya. Kemudian nilai error ini dapat menghasilkan nilai MAPE sebesar 26,92\% dan rekapulasi dapat dilihat pada Tabel 10 .

b. Menghitung double exponential smoothing $\alpha=0,9$

1) Penentuan nilai Smoothing yang pertama $\left(\mathrm{S}^{\prime} \mathrm{t}\right)$ 


$$
\begin{aligned}
& \mathrm{S}_{{ }_{1}}=320.000 \\
& \mathrm{~S}_{{ }_{2}}=(364.000 \times 0,9)+(1-0,9) \times 320.000=359.600 \\
& \mathrm{~S}_{27}^{\prime}=(340.000 \times 0,9)+(1-0,9) \times 406.708=346.670
\end{aligned}
$$

2) Penentuan nilai Smoothing yang kedua $(\mathrm{S} " \mathrm{t})$

$\mathrm{S}_{1}=320.000$

$\mathrm{S}_{2}=(359.600 \times 0,9)+(1-0,9) \times 320.000=355.640$

$\mathrm{S}_{27}=(346.670 \times 0,9)+(1-0,9) \times 377.897=349.793$

3) Penentuan Besarnya Konstanta $(\alpha \mathrm{t})$

$$
\begin{aligned}
& a_{1}=(2 \times 320.000)-320.000=320.000 \\
& a_{27}=(2 \times 346.670)-349.793=343.548
\end{aligned}
$$

4) Penentuan Besarnya Slope (bt)

$$
\begin{aligned}
& \mathrm{b}_{1}=\frac{0,9}{1-0,9}(320.000-320.000)=0 \\
& \mathrm{~b}_{27}=\frac{0,9}{1-0,9}(346.670-349.793)=28.104
\end{aligned}
$$

5) Penentuan besarnya peramalan $(\mathrm{Ft}+\mathrm{m})$

$$
\begin{aligned}
& \mathrm{F}_{\mathrm{t}+\mathrm{m}}=\mathrm{a}_{\mathrm{t}}+\mathrm{b}_{\mathrm{t}} \mathrm{m} \\
& \text { Untuk } \mathrm{t}=1 \text { dan } \mathrm{m}=1 \\
& \mathrm{~F}_{1+1}=320.000+0(1) \\
& \mathrm{F}_{2}=320.000 \\
& \text { Untuk } \mathrm{t}=2 \text { dan } \mathrm{m}=1 \\
& \mathrm{~F}_{2+1}=363.560+35.640(1) \\
& \mathrm{F}_{3}=399.200 \\
& \text { Untuk } \mathrm{t}=27 \text { dan } \mathrm{m}=1 \\
& \mathrm{~F}_{27+1}=343.548+28.104(1) \\
& \mathrm{F}_{28}=371.652
\end{aligned}
$$

Tabel 4. Hasil Perhitungan DES $\boldsymbol{\alpha}=0,9$

\begin{tabular}{cccccc}
\hline $\begin{array}{c}\text { Periode } \\
(\mathrm{t})\end{array}$ & $\begin{array}{c}\text { Demand } \\
(\mathrm{x})\end{array}$ & $\mathrm{S}^{\prime} \mathrm{t}$ & $\mathrm{S}$ 't & $\mathrm{a}$ & $\mathrm{b}$ \\
\hline 1 & 320.000 & & & & \\
2 & 364.000 & 320.000 & 320.000 & 320.000 & 0 \\
3 & 438.000 & 359.600 & 355.640 & 363.560 & 35.640 \\
4 & 340.000 & 430.160 & 422.708 & 437.612 & 67.068 \\
5 & 408.000 & 349.016 & 356.385 & 341.647 & -66.323 \\
6 & 328.000 & 402.102 & 397.530 & 406.673 & 41.145 \\
7 & 324.000 & 335.410 & 341.622 & 329.198 & -55.908 \\
8 & 332.000 & 325.141 & 326.789 & 323.493 & -14.833 \\
$\ldots$ & $\ldots$ & $\ldots$ & $\ldots$ & $\ldots$ & $\ldots$ \\
24 & 96.000 & 206.896 & 222.157 & 191.635 & -137.347 \\
25 & 440.000 & 107.090 & 118.596 & 95.583 & -103.560 \\
26 & 340.000 & 406.709 & 377.898 & 435.520 & 259.301 \\
27 & 380.000 & 346.671 & 349.794 & 343.548 & 28.104 \\
\hline \multicolumn{7}{c}{ Total } & 9.919 .037 & 9.915 .726 & 9.922 .347 & 86.002 \\
\hline
\end{tabular}

Sumber: Hasil pengolahan data (2021)

Didapatkan hasil rekapulasi dari perhitungan double exponential smoothing $\boldsymbol{\alpha}=0,9$ kemudian hasil ini dilanjutkan untuk menghitung nilai error dari masing-masing periode.

Tabel 5. Nilai Error Perhitungan DES $\boldsymbol{\alpha}=0,9$

\begin{tabular}{cccc}
\hline $\begin{array}{c}\text { Periode } \\
\mathrm{t}\end{array}$ & $\begin{array}{c}\text { Error } \\
\text { At-Ft }\end{array}$ & $\begin{array}{c}{[\text { Error }]} \\
\mid \text { At-Ft } \mid\end{array}$ & $\begin{array}{c}\text { \%Erorr } \\
\text { (At-Ft)/At*100 }\end{array}$ \\
\hline 1 & & & \\
2 & 44.000 & 44.000 & 12,09 \\
3 & 82.360 & 82.360 & 18,80 \\
4 & -82.708 & 82.708 & 24,33 \\
5 & 51.615 & 51.615 & 12,65 \\
6 & -69.530 & 69.530 & 21,20 \\
\hline
\end{tabular}




\begin{tabular}{cccc}
\hline 7 & -17.622 & 17.622 & 5,44 \\
8 & 5.211 & 5.211 & 1,57 \\
$\ldots$ & $\ldots$ & $\ldots$ & $\ldots$ \\
24 & -126.157 & 126.157 & 131,41 \\
25 & 321.404 & 321.404 & 73,05 \\
26 & -37.898 & 37.898 & 11,15 \\
27 & 30.206 & 30.206 & 7,95 \\
\hline \multicolumn{5}{c}{ MAPE } \\
\hline \multicolumn{5}{c}{ Sumber: Hasil pengolahan data $(2021)$}
\end{tabular}

Pada tabel di atas merupakan nilai error yang diperoleh dari hasil perhitungan double exponential smoothing $\boldsymbol{\alpha}=0,9$ pada tiap periodenya. Kemudian nilai error ini dapat menghasilkan nilai MAPE sebesar 26,22\% dan rekapulasi dapat dilihat pada Tabel 10.

c. Menghitung moving average $\mathrm{n}=3$

$$
\begin{aligned}
& \mathrm{MA}=\frac{\Sigma A_{t}}{n} \\
& \mathrm{MA}_{3}=\frac{\left(\mathrm{A}_{1}+\mathrm{A}_{2}+\mathrm{A}_{3}\right)}{3}=374.000,00
\end{aligned}
$$

Tabel 6. Hasil Perhitungan MA $\mathrm{n}=3$

\begin{tabular}{ccc}
\hline $\begin{array}{c}\text { Periode } \\
\mathrm{t}\end{array}$ & $\begin{array}{c}\text { Demand } \\
\text { At }\end{array}$ & $\begin{array}{c}\text { Forecast } \\
\mathrm{Ft}\end{array}$ \\
\hline 1 & 320.000 & \\
2 & 364.000 & \\
3 & 438.000 & \\
4 & 340.000 & 374.000 \\
5 & 408.000 & 380.667 \\
6 & 328.000 & 395.333 \\
7 & 324.000 & 358.667 \\
8 & 332.000 & 353.333 \\
$\ldots$ & $\ldots$ & $\ldots$ \\
24 & 96.000 & 348.000 \\
25 & 440.000 & 202.667 \\
26 & 340.000 & 242.667 \\
27 & 380.000 & 292.000 \\
\hline \multicolumn{4}{c}{ Sumber: Hasil pengolahan data $(2021)$}
\end{tabular}

Didapatkan hasil rekapulasi dari perhitungan moving average $\boldsymbol{n}=3$ kemudian hasil ini dilanjutkan untuk mendapatkan nilai error dari masing-masing periode.

Tabel 7. Nilai Error Perhitungan MA $\boldsymbol{n}=3$

\begin{tabular}{cccc}
\hline $\begin{array}{c}\text { Periode } \\
\mathrm{t}\end{array}$ & $\begin{array}{c}\text { Error } \\
\text { At-Ft }\end{array}$ & $\begin{array}{c}{[\text { Error }]} \\
\mid \text { At-Ft } \mid\end{array}$ & $\begin{array}{c}\text { \%Erorr } \\
(\text { At-Ft }) / A A^{*} 100\end{array}$ \\
\hline 1 & & & \\
2 & & & \\
3 & & 34.000 & 10,00 \\
4 & -34.000 & 27.333 & 6,70 \\
5 & 27.333 & 67.333 & 20,53 \\
6 & -67.333 & 34.667 & 10,70 \\
7 & -34.667 & 21.333 & 6,43 \\
8 & -21.333 & $\ldots$ & $\ldots$ \\
$\ldots$ & $\ldots$ & 252.000 & 262,50 \\
24 & -252.000 & 237.333 & 53,94 \\
25 & 237.333 & 97.333 & 28,63 \\
26 & 97.333 & 88.000 & 23,16 \\
27 & 88.000 & 32,46 \\
\hline \multicolumn{5}{c}{ MAPE }
\end{tabular}


Pada Tabel 7 merupakan nilai error yang diperoleh dari hasil perhitungan moving average $\boldsymbol{n}=3$ pada tiap periodenya. Kemudian nilai error ini dapat menghasilkan nilai MAPE sebesar 32,46\% dan rekapulasi dapat dilihat pada Tabel 10.

d. Menghitung moving average $\mathrm{n}=4$

$$
\begin{aligned}
& \mathrm{MA}=\frac{\Sigma A_{t}}{n} \\
& \mathrm{M} A_{4}=\frac{\left(A_{1}+A_{2}+A_{3}+A_{4}\right)}{4}=365.500,00
\end{aligned}
$$

Tabel 8. Hasil perhitungan MA $\mathrm{n}=4$

\begin{tabular}{ccc}
\hline $\begin{array}{c}\text { Periode } \\
\mathrm{t}\end{array}$ & $\begin{array}{c}\text { Demand } \\
\mathrm{At}\end{array}$ & $\begin{array}{c}\text { Forecast } \\
\mathrm{Ft}\end{array}$ \\
\hline 1 & 320.000 & \\
2 & 364.000 & \\
3 & 438.000 & \\
4 & 340.000 & \\
5 & 408.000 & 365.500 \\
6 & 328.000 & 387.500 \\
7 & 324.000 & 378.500 \\
8 & 332.000 & 350.000 \\
$\ldots$ & $\ldots$ & $\ldots$ \\
24 & 96.000 & 391.000 \\
25 & 440.000 & 285.000 \\
26 & 340.000 & 262.000 \\
27 & 380.000 & 267.000 \\
\hline
\end{tabular}

Sumber: Hasil pengolahan data (2021)

Didapatkan hasil rekapulasi dari perhitungan moving average $\boldsymbol{n}=4$ kemudian hasil ini dilanjutkan untuk mendapatkan nilai error dari masing-masing periode.

Tabel 9. Hasil Perhitungan MA $\mathrm{n}=4$

\begin{tabular}{cccc}
\hline $\begin{array}{c}\text { Periode } \\
\mathrm{t}\end{array}$ & $\begin{array}{c}\text { Error } \\
\mathrm{At}-\mathrm{Ft}\end{array}$ & $\begin{array}{c}{[\text { Error }]} \\
\mid \text { At-Ft }]\end{array}$ & $\begin{array}{c}\text { \%Erorr } \\
(\mathrm{At}-\mathrm{Ft}) / \mathrm{At} *^{*} 100\end{array}$ \\
\hline 1 & & & \\
2 & & & \\
3 & & & \\
4 & & \\
5 & 42.500 & 42.500 & 10,42 \\
6 & -59.500 & 59.500 & 18,14 \\
7 & -54.500 & 54.500 & 16,82 \\
8 & -18.000 & 18.000 & 5,42 \\
$\ldots$ & $\ldots$ & $\ldots$ & $\ldots$ \\
24 & -295.000 & 295.000 & 307,29 \\
25 & 155.000 & 155.000 & 35,23 \\
26 & 78.000 & 78.000 & 22,94 \\
27 & 113.000 & 113.000 & 29,74 \\
\hline \multicolumn{4}{c}{ MAPE } \\
\hline \multicolumn{4}{c}{ Sumber: Hasil pengolahan data $(2021)$}
\end{tabular}

Pada Tabel 9 merupakan nilai error yang diperoleh dari hasil perhitungan moving average $\boldsymbol{n}=4$ pada tiap periodenya. Kemudian nilai error ini dapat menghasilkan nilai MAPE sebesar $34,77 \%$ dan rekapitulasi dapat dilihat pada Tabel 10.

e. Rekapitulasi Nilai MAPE

Pada pengolahan data di atas diketahui hasil dan nilai error dari masing-masing metode. Nilai error yang diperoleh mendapatkan hasil perhitungan MAPE yang akan direkapitulasi untuk mengetahui nilai MAPE terendah dari masing-masing metode dan metode peramalan apa dari kedua metode di atas yang akan diterapkan. 
Tabel 10. Rekapitulasi Hasil Perhitungan MAPE

\begin{tabular}{cc}
\multicolumn{3}{c}{ MAPE } \\
\hline MA 3 & 32,46 \\
MA 4 & 34,77 \\
DES 0,8 & 26,92 \\
DES 0,9 & $\mathbf{2 6 , 2 2}$ \\
\hline \multicolumn{2}{c}{ Sumber: Hasil pengolahan data (2021) }
\end{tabular}

Pada Tabel 10 didapatkan hasil MAPE dari kedua metode peramalan. Metode peramalan dengan nilai MAPE terendah didapatkan dengan menggunakan metode double exponential smoothing dengan $\boldsymbol{\alpha}=0$,9. Maka metode double exponential smoothing dengan $\boldsymbol{\alpha}=0,9$ dalam kasus ini terpilih sebagai metode peramalan yang digunakan untuk meramalkan permintaan produk gasket cap.

\section{Kesimpulan}

Dalam memperkirakan permintaan produk gasket cap PT. Nesinak Industries harus melakukan peramalan untuk mengetahui seberapa banyak permintaan produk di masa mendatang. Berdasarkan hasil perhitungan dapat disimpulkan dalam nilai MAPE terendah dihasilkan dengan menggunakan metode DES $\boldsymbol{\alpha}=0,9$ dengan nilai MAPE sebesar 26,22 \% nilai tersebut lebih rendah daripada double exponential smoothing $\boldsymbol{\alpha}=0,8$, moving average $\mathrm{n}=3$, dan moving average $\mathrm{n}=4$. Pada perhitungan kali ini, double exponential smoothing $\boldsymbol{\alpha}=0,9$ dapat dipilih sebagai metode peramalan untuk perhitungan ini.

\section{Referensi}

[1] N. L. A. K. Yuniastari and I. W. W. Wirawan, "Peramalan Permintaan Produk Perak Menggunakan Metode Simple Moving Average Dan Exponential Smoothing," J. Sist. dan Inform., vol. 9, no. 1, pp. 97-106, 2014.

[2] Aden and A. Supriyanti, "Prediksi Jumlah Calon Peserta Didik Baru Menggunakan Metode Double Exponential Smoothing Dari Brown ( Study Kasus : SD Islam Al-Musyarrofah Jakarta )," J. Ilm. Pendidik. Mat. Mat. dan Stat., vol. 1, no. 1, pp. 56-62, 2020.

[3] D. Purwanti and J. Purwadi, "Metode Brown' s Double Exponential Smoothing dalam Peramalan Laju Inflasi di Indonesia," J. Ilm. Mat., vol. 6, no. 2, pp. 54-61, 2019.

[4] E. Pujiati, D. Yuniarti, and R. Goejantoro, "Peramalan Dengan Menggunakan Metode Double Exponential Smoothing Dari Brown ( Studi Kasus: Indeks Harga Konsumen ( IHK ) Kota Samarinda ) Forecasting Using Double Exponential Smoothing Method Of Brown ( Case Study : The Consumer Price Index ( CPI ) City," J. Eksponensial, vol. 7, 2016.

[5] Kusyanto, D. Suhardi, and R. Awaluddin, "Peramalan Penjualan Keramik Menggunakan Metode Moving Average Dan Exponential Smoothing Pada Usaha Agus Keramik," J. Ekon. Akunt. Dan Manaj., vol. 1, no. 1, pp. 12-21, 2020.

[6] F. Sutisna and Hendy, "Analisis Perbandingan Tingkat Kesalahan Metode Peramalan Sebagai Upaya Perencanaan Pengelolaan Persediaan yang Optimal pada PT Duta Indah Sejahtera," J. Bina Manaj., vol. 8, no. 1, pp. 34-57, 2019.

[7] Sugiyono, Metode penelitian pendidikan pendekatan kuantitatif, kualitatif dan R\&D. Bandung: Alfabeta, 2014.

[8] Sugiyono, Metode Penelitian Kombinasi (Mix Methods). Bandung: Alfabeta, 2015.

[9] Sugiyono, Metode Penelitian Kuantitatif, Kualitatif Dan R\&D. Bandung: PT. Alfabet, 2016.

[10] M. Kasiram, Metodologi Penelitian Kuantitatif-Kualitatif. Malang: Uin Maliki Press, 2010.

[11] H. D. P. Habsari, I. Purnamasari, and D. Yuniarti, "Peramalan Menggunakan Metode Double Exponential Smoothing dan Verifikasi Hasil Peramalan Menggunakan Grafik Pengendali Tracking Signal," J. Ilmu Mat. dan Terap., vol. 14, no. 1, pp. 13-22, 2020.

[12] R. Y. Irawan, W. Laksito, and Setiyowati, "Penerapan Metode Double Exponential Smoothing Untuk Peramalan Tingkat Indeks Pembangunan Manusia Berbasis Sistem Informasi Geografis Di Provinsi Jawa Tengah,” J. TIKomSiN, vol. 7, no. 2, pp. 18-28, 2019.

[13] C. R. Miranda, E. J. Kaesang, M. Seby, and A. T. Suprapto, "Analisa Pengendalian Persediaan Produk Sepatu Menggunakan Metode Forcasting, EOQ Dan Monte Carlo Pada PT Kirana Abadi Sentosa," J. Manaj. Pemasar., vol. 9, no. 1, pp. 34-41, 2019.

[14] J. Heizer and B. Render, Manajemen Operasi : Manajemen Keberlangsungan dan Rantai Pasokan, 11th ed. Jakarta: Salemba Empat, 2015. 
[15] D. A. Setiawan, S. Wahyuningsih, and R. Goejantoro, "Peramalan Produksi Kelapa Sawit Menggunakan Winter' s dan Pegel's Exponential Smoothing dengan Pemantauan Tracking Signal," Jambura J. Math., vol. 2, no. 1, pp. 1-14, 2020. 